IP Periodica Polytechnica Civil Engineering

\author{
62(2), pp. 330-336, 2018 \\ https://doi.org/10.3311/PPci.11311 \\ Creative Commons Attribution (1)
}

RESEARCH ARTICLE

\section{In-plane Shear Strengthening of Unreinforced Masonry Walls Using GFRP Jacketing}

\author{
Enea Mustafaraj $^{1 *}$, Yavuz Yardim ${ }^{2}$
}

Received 27 July 2017; Revised 11 October 2017; Accepted 31 October 2017

\begin{abstract}
In this paper, it is presented the experimental results of a campaign on diagonal compression tests, as of ASTM E519-02, to assess and compare the in-plane behavior of standard size of $1200 \times 1200 \times 250 \mathrm{~mm}$, for three unreinforced and three reinforced wall panels by glass fiber reinforced polymer (GFRP) embedded in an inorganic matrix.

From the diagonal compression test results, were determined some of the main mechanical parameters such as: shear strength, modulus of rigidity and ductility, before and after application of the reinforcement.

The experimental results showed that the GFRP reinforced panels exhibited a significant increase of $127 \%$ in shear resistance, $1100 \%$ in ductility and $650 \%$ in modulus of rigidity when compared to unreinforced panels.

It was concluded that this technique provided satisfactory results and can be considered a suitable method for repair of masonry structures.
\end{abstract}

\section{Keywords}

unreinforced masonry structures, diagonal compression test, GFRP mesh, composite material, structural rehabilitation

\footnotetext{
1 Department of Civil Engineering,

Epoka University, Tirana, Albania

2 School of Engineering,

The University of Edinburgh, Edinburgh, UK

* Corresponding author, email: emustafaraj@epoka.edu.al
}

\section{Introduction}

Unreinforced masonry (URM) buildings are one of the most used construction type in Europe, around the Mediterranean basin and Balkan peninsula. These regions are characterized with medium-to-high levels of seismic hazard. A vast number of URM buildings in these regions are vulnerable against earthquakes which are acknowledged to be one of the major cause of their damage, often even for their collapse. In such event, the load bearing walls are subjected to a combination of lateral seismic forces, that are in the form of out-of-plane or in-plane loading depending on the orientation of the building with seismic loading direction.

Masonry structures, under such type of loading condition, manifest a brittle behavior, a relatively poor performance and are susceptible to high degrees of structural damage. Since the out-of-plane failure could be avoided by additional structural elements, the overall seismic performance of URM buildings depends on the capacity of in-plane walls to safely transfer the lateral loads to foundations, providing the post-earthquake stability necessary to avoid collapse of the entire structure [1].

Moreover, during their lifespan, many of those buildings have suffered from the combined effects of inadequate construction techniques, seismic and wind loads, foundation settlements and deterioration of construction materials [2].

To increase low parameters of masonry such as tensile and shear strength, as well as to improve the poor structural performance of URM structures under seismic actions, various strengthening techniques have been developed and applied throughout history of construction. The earliest techniques, the so-called traditional, consist of applying the reinforcement in form of: (i) filling cracks and voids by grouting; ii) stitching of large cracks and weak areas with metallic or brick elements; iii) external or internal post-tensioning with steel ties; iv) shotcrete jacketing; v) ferrocement and vi) center core etc. [3,4].

Some successful examples of ferrocement jacketing have been observed in concrete structures [5-8] as well as in masonry structures where ferrocement provided a considerable increase in ductility, improvement of crack resistance $[9,10]$, and increased stiffness and load carrying capacity as well as increase of in-plane resistance [11-15]. 
Despite their success, in many cases, application of traditional strengthening techniques has been prevented due to some limitations such as: time consuming, reduction of available space, occupancy disturbance, building operation disturbance and affecting the aesthetics of the existing wall.

These constrains may be overcome by using modern techniques for retrofitting such as reinforced polymer jacketing or reinforced mortar. They could improve the structural behavior of masonry under monotonic, seismic or explosive loads with a negligible added mass and stiffness without altering the dynamic properties of the strengthened structure.

Textile reinforced mortar (TRM) is a good alternative which combines the essential properties of both conventional and modern materials by using textile grids externally embedded in mortars. The composite action of TRM is achieved through the mechanical interlock of the grid structure (made of long fiber roving of carbon, glass or aramid arranged in two orthogonal directions) and the mortar (made of cement or lime-based instead of polymer resins) [16].

Another modern technique consists of fiber reinforced polymer system made of two main materials: resin and fibers. These Fiber Reinforced Polymer (FRP) composites are made of carbon (CFRP), glass (GFRP) or aramid (AFRP) fibers bonded together in an inorganic polymeric matrix (such as putty fillers, saturants and adhesives like epoxy, polyester or vinylester) that offer many advantages such as high strength and stiffness in the direction of the fibers, immunity to corrosion, low weight, availability in various forms as laminates, fabrics and tendons of unlimited lengths, exceptional durability in many environments, cost effectiveness.

Retrofitting of URM wall with FRP is a promising technique as it was observed that FRP improves the in-plane lateral resistance by 1.1-3 times and the out-of-plane resistance by more than 7 times. In order to improve out-of-plane failure, the research was mainly focused on monotonic and static cyclic loading. These experiments showed that FRP increased the URM flexural strength. The modes of failure of the tested FRP-strengthened specimens are as follows [4, 17-20]:

a) sliding shear: complete separation at mortar joints in the shear region with a fracture in fiber material;

b) flexural failure: caused by masonry compression failure or the rupture of the fibers;

c) combination shear-flexural failure: cracks started at the maximum bending region and continue $45^{\circ}$ as a shear crack;

d) delamination;

e) combination of delamination and pullout of face shell;

f) interface shear failure in multiple wall leaf.

FRP composite strips were used by Gabor et al., to reinforce masonry panels and test them in diagonal compression. There were used 3 types of them; unidirectional glass fiber (RFV), unidirectional carbon fiber (RFC) and bi-directional glass fiber
(RFW). It was observed that the failure strength was governed by shear strength induced by the interaction of mortar with the internal wallettes at the brick/mortar interface. It was observed that the seismic behavior was improved as the deformations corresponding to the maximum loads of the reinforced walls were three times higher than the ones of URM walls [21].

Valluzzi et al., investigated the efficiency of strengthening of brick masonry panels with by FRP laminates using different reinforcement configurations. They conducted experiments in order to study the shear behavior of masonry panels reinforced with FRP laminates by testing in diagonal compression a series of nine unreinforced masonry (URM) panels and 24 strengthened panels were subjected to diagonal compression tests. As it was seen from the results, double-side configurations provided a less brittle failure and a noticeable ultimate capacity increase [22].

Gattesco and Boem conducted diagonal compression tests to compare the in-plane behavior of unreinforced masonry and of masonry strengthen with a GFRP mortar coating using wallettes of different masonry types and thickness as well as different mortar types for coatings [23].

Another modern technique used for strengthening is fiber reinforced polymer systems made of fibers (carbon, glass or aramid) bonded in an inorganic polymeric matrix (such as putty fillers, saturants and epoxy polyester or vinylester like adhesives).

In recent years, there have been carried out considerable research studies in determining the structural behavior of masonry buildings subjected to seismic forces. It has lead towards development of new codes for masonry construction and design such as Eurocode 6- Design of masonry structures [24]. Tomazeviç investigated the diagonal shear strength and compared the results with the equations suggested by Eurocode 6 [25]. Other researchers have investigated brick-mortar bond strength and the response of URM under in-plane direct shear forces [26-30].

Most of the researches conducted so far, have been considering separately the behavior of URM walls under in-plane or out-of-plane loading. Najafgholipour et al., suggested that the wall aspect ratio has a high influence on the interaction level. They noticed an interaction between in-plane shear and outof-plane bending capacities of the brick walls. This interaction becomes stronger when one of the loading types is near the wall's ultimate capacity in any of the loading directions [31].

During the last decades, the feasibility of usage of GFRP reinforcement techniques as a good method to improve shear resistance of URM walls has been studied by many researchers [32-40].

Badoux et al., investigated the dynamic in-plane behavior of URM walls by using half-scale hollow clay masonry walls subjected to a series of simulated seismic earthquake motions before reinforcing with GFRP. The presence of GFRP 
prevented the development of cracks through the wall panel until masonry crushing at the bottom corners occurred resulting in a "balanced" upgraded wall reinforcement [33].

Turco et al., analyzed retrofitted walls with glass and carbon FRP and observed two types of modes of failure: debonding of FRP reinforcement and shear failure of masonry at the support, when specimens were loaded diagonally. The strength was increased up to 2.5 times in shear strengthening and 4.5-26 times in case of flexural strengthening. Even though it has a lower modulus of elasticity, GFRP performed better than CFRP [34].

Fam et al., used the combination of injection and GFRP strengthening techniques in order to repair deteriorated walls. It was observed that this combination recovered and even improved the capacity of the walls [35].

Wang et al., carried out experiments on eight brick masonry walls reinforced with GFRP, and observed that this method increased the load carrying capacity of masonry subjected to in-plane shear loading [36].

Kalali and Kabir, presented an experimental study focused on the in-plane behavior of unreinforced brick (URB) walls before and after retrofitting, using glass fiber reinforced polymers (GFRPs) aiming to investigate the efficiency of shear reinforcing technique. The test specimens were built in such a way to simulate the traditional masonry walls built in Iran [3].

Corradi et al., carried out in-situ tests on masonry panels on the structures damaged during the Umbria-Marche earthquake of 1997-1998. The main aim was to suggest a technique for seismic upgrade against in-plane mechanisms of collapse using lime based mix injection over layers of CFRP and GFRP meshes [37].

Corradi et al., carried out experimental tests on historic masonry wall panels reinforced with GFRP jacketing inserted into inorganic matrix. In-situ tests were done on panels from two different sites in Italy; 2 double leaf rubble stone masonry and one solid brick masonry. The panel shear strength was determined before and after reinforcement by means of diagonal compression test and shear-compression tests. It was observed that the panels reinforced with GFRP exhibited a significant improvement in lateral load-carrying capacity up to $1060 \%$ when compared with control panels [38].

\section{Materials and Methods}

The experimental campaign in this study consists of destructive tests on six masonry panels (unreinforced and reinforced with GFRP jacketing) to determine the main mechanical properties of bricks, mortar and masonry assemblage. The testing procedures are the ones defined in American Society for Testing and Materials (ASTM) where are defined all the steps to be followed. These standards have been used by many researchers who have experimented with unreinforced clay brick masonry all over the world [3, 13-15, 40-43, 48].

\subsection{Construction of plain panels}

The plain wall panels were built using two leaf, English bond and new clay bricks with typical nominal dimensions of 243.4 $\mathrm{mm} \times 118.9 \mathrm{~mm} \times 56.8 \mathrm{~mm}$ with $15 \mathrm{~mm}$ thick mortar joints made of hydraulic cement mortar of type " $\mathrm{N}$ " with a volumetric mix ratio of cement: lime: sand, 1:1:6 (Figure 1). The average compressive strength of the bricks, $f_{b}$, was $24.03 \mathrm{MPa}$, and the average compressive strength of mortar, $f_{j}$, was $5.68 \mathrm{MPa}$.

\subsection{G-FRP jacketing reinforced panels}

The strengthening technique used for W4-GFRP, W5-GFRP, W6-GFRP involved the attachment of a single-layered GFRP mesh (with the same dimensions as the panel) on both sides of the plain wall embedded on an inorganic matrix of mortar coating of $25 \mathrm{~mm}$ thickness (Figure 2 and Figure 3). The technical specifications of GFRP mesh are presented in Table 1.

The mesh is fixed using anchors (threaded bolts of diameter $8 \mathrm{~mm}$ and length $70 \mathrm{~mm}$ with washers, mounted on previously drilled holes, having $10 \mathrm{~mm}$ wall plugs on the bricks every $30 \mathrm{~cm}$ ). The spacing of the connections was slightly changed depending on the brick arrangements, ensuring that the connection was done on the brick and not on the mortar joint. The process of mounting the mesh on the faces of the wall was done carefully and a 5-10 $\mathrm{mm}$ allowance between mesh and the bricks for plaster mortar. The inorganic matrix was a coating layer of hydraulic cement mortar of cement: sand volumetric ratio of 1:1 and water/cement ratio of 0.4 .
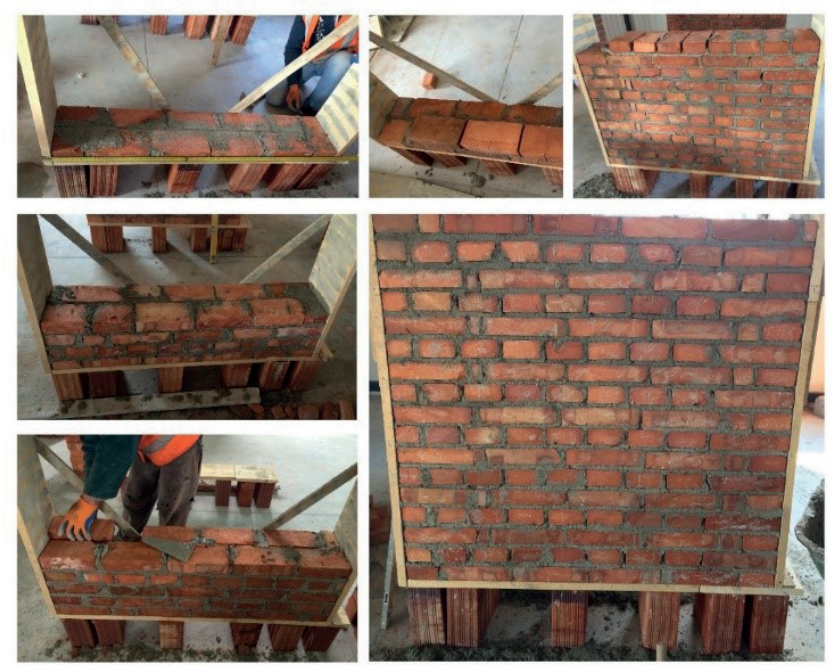

Fig. 1 Construction process of plain walls 


\begin{tabular}{lc}
\multicolumn{2}{l}{ Table 1 Technical specification for GFRP mesh (SikaWrap ${ }^{\circledR}$ Hex $\left.106 \mathrm{G}\right)$} \\
\hline Primary Fiber Direction & $0^{\circ} / 90^{\circ}$ (bi-directional) \\
Weight & $325 \mathrm{~g} / \mathrm{m}^{2}$ \\
Weight Ratio (Warp: Weft) & $1: 1$ \\
Cured Laminate Properties $\left(0^{\circ} \& 90^{\circ}\right)$ & Design Values \\
\hline Tensile Strength & $244 \mathrm{MPa}$ \\
Modulus of Elasticity & $16215 \mathrm{~N} / \mathrm{mm}^{2}$ \\
Elongation at Break & $1.43 \%$ \\
Thickness & $0.33 \mathrm{~mm}$ \\
Strength per cm width & $2.53 \mathrm{kN}$ \\
Fiber Properties & \\
\hline Tensile Strength & $2,276 \mathrm{MPa}$ \\
Tensile Modulus & $72,390 \mathrm{MPa}$ \\
Elongation & $4 \%$ \\
Density & $2.54 \mathrm{~g} / \mathrm{cc}$ \\
\hline
\end{tabular}

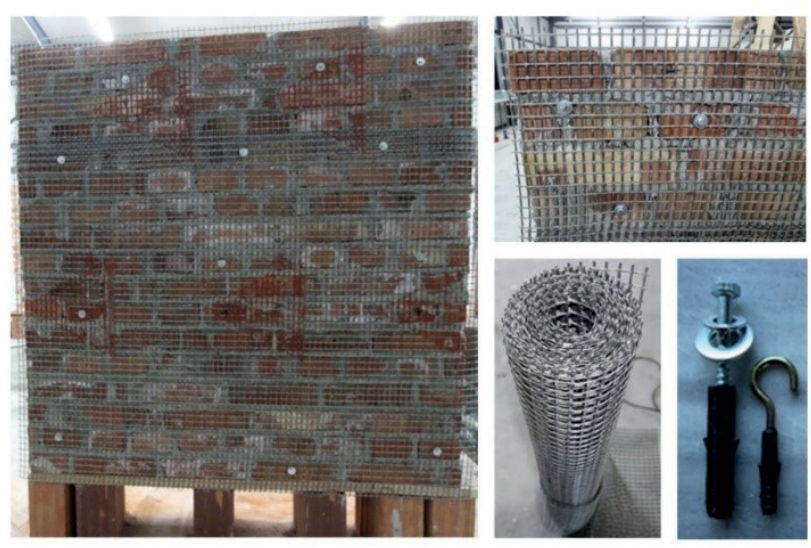

Fig. 2 Plastering process with GFRP

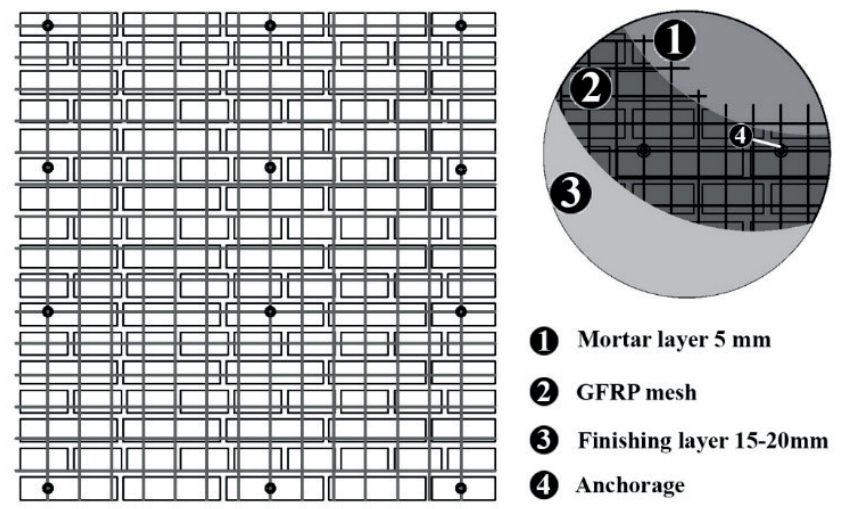

Fig. 3 Plastering process with GFRP (schematic view)

\subsection{Specimen characteristics}

All the wall panels were built in laboratory by experienced masons and were left to cure for 28 days prior to either testing or reinforcing. After that time, a layer of white lime paint was applied to provide a better medium for analyzing the crack formation. The naming of the specimens was done in the following manner: "W" is designated for the standard sized wall panel of $1200 \times 1200 \times 250 \mathrm{~mm}$, and GFRP represents the plastering method of the specimens (glass fiber reinforced polymer jacketing).
The panels were also tested in their own place. The testing system was designed in such a way that no disturbance would be caused to the walls. The testing continued until the wall panels failed; when after the main diagonal crack was seen sudden drop of the ultimate load (it reached to zero up to a few tones).

\subsection{Test procedure}

ASTM E 519-07 [45] is a test method used to determine the diagonal tensile or shear strength of 1.2 by $1.2 \mathrm{~m}$ masonry assemblages by loading them in compression along one diagonal, thus causing a diagonal tension failure with the specimen splitting apart parallel to the direction of load.

The movable test set-up consists of two loading shoes placed on two diagonally opposite corners of the panel connected by four high strength steel rods positioned along the compressed diagonal (Figure 4).

The calculation procedure is as follows:

$$
S_{s}=\frac{0.707 \boldsymbol{P}}{A_{n}}
$$

where:

$\boldsymbol{S}_{s}$ - shear stress (MPa); $\boldsymbol{P}$ - load exerted along the compression diagonal (N); $\boldsymbol{A}_{n}-$ net area of the specimen $\left(\mathrm{mm}^{2}\right)$;

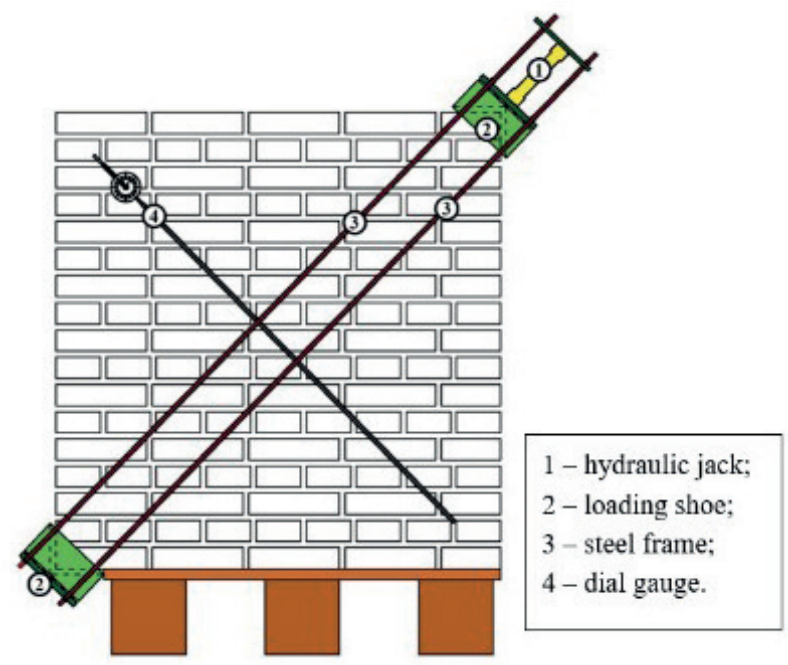

Fig. 4 Diagonal compression test set-up

$$
A_{n}=\frac{w+h}{2} t \cdot n
$$

where:

$\boldsymbol{w}$ - width of specimen (mm); $\boldsymbol{h}$ - height of specimen (mm); $\boldsymbol{t}$ - total thickness of specimen ( $\mathrm{mm}) ; \boldsymbol{n}$ - percent of the gross area of the unit that is solid, expressed as a decimal.

$$
\gamma=\frac{\Delta \boldsymbol{V}+\Delta \boldsymbol{H}}{g}
$$

where:

$\boldsymbol{\gamma}$ - shear strain $(\mathrm{mm} / \mathrm{mm}) ; \Delta \boldsymbol{V}$ - vertical shortening $(\mathrm{mm})$; $\Delta \boldsymbol{H}$ - horizontal extension; $\boldsymbol{g}$ - vertical gage length; 


$$
G=\frac{S_{n}}{\gamma}
$$

where:

\section{$\boldsymbol{G}$ - modulus of rigidity, MPa.}

The shear modulus of the panel was calculated using the secant modulus of $0.05 \tau_{\max }$ and $0.70 \tau_{\max }$ of the stress-strain response curve. The stiffness of a wall specimen can be quantified by the Modulus of Elasticity, $E$, which is related to shear modulus by the following Equation 5, where $v=0.25$ adopted by [46]:

$$
E=2 G \cdot(1+v)
$$

Ductility of the tested wall panels, a drift ratio was defined as:

$$
\gamma_{u}=\frac{\Delta u}{H}
$$

where $\Delta u$, is the diagonal displacement corresponding to the ultimate strength and $H$ is the height of the wall panel.

\section{Results and Discussion}

The plain wall panels had a similar failure mode; a sudden drop in resistance after cracking along the compressed diagonal, predominantly through the mortar joints in a diagonal step pattern. Nevertheless, in some cases, sliding along the mortar bed joints, following by diagonally extended cracks was observed (Figure 5a, b). The overall failure mode can be categorized as tension failure followed by shear-sliding along the compressed diagonal in a step-like pattern mainly observed in W3. For the remaining other two panels (W1 and W2), shear sliding started at the third course from top of the panel, continued horizontally along the bed joint at an approximate length of $500 \mathrm{~mm}$, and then propagated in a diagonal step-like pattern exclusively through the mortar joints.

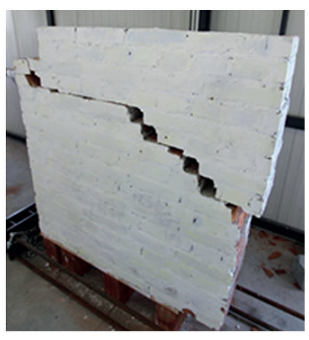

(a)

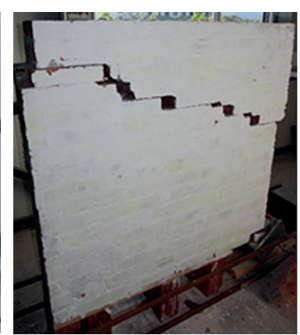

(b)

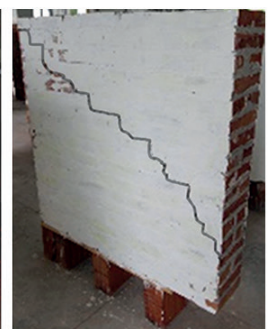

(c)
Fig. 5 Failure mode of plain walls

In GFRP reinforced wall panels, a clear linear splitting crack in the plastering layer along the compressed diagonal was observed in all three specimens just before reaching the ultimate load (Figure 6). The cracked area is expanded gradually with other cracks parallel to the main diagonal until failure of the reinforcing mesh was reached. The mesh yielded in all these cases indicating that this technique was properly applied.

The shear stress-strain response is presented in Figure 7. For all the wall panels, the experimental curve was approximately linear prior to crack initiation, followed by a nonlinear portion of the curve up to the maximum strength. This similar behavior was also observed in other studies [38, 47-49].
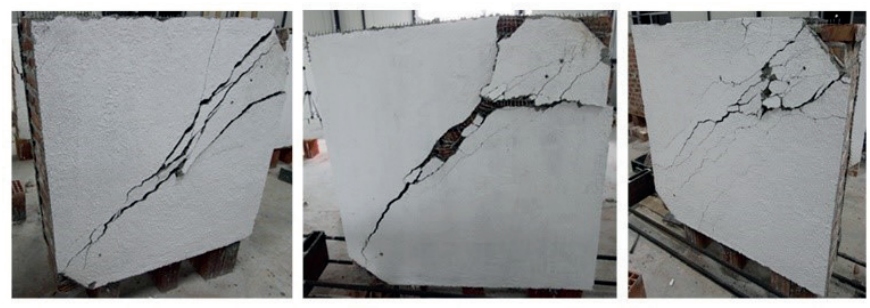

Fig. 6 Failure mode of GFRP strengthened wall panels

The curves are plotted to a scale of a maximum strain, $\varepsilon_{\max }$, 0.005 which corresponds to a drift of $0.5 \%$ (which is the allowable drift limit for design of masonry structures, considered to be an optimum value where the comparisons of all the experiments may be presented. The plain wall panels are very brittle, and the stress-strain response is very short. As it can be seen from Figure 7, the GFRP reinforced panels, W4-GFRP and W5-GFRP exhibited considerably higher shear stresses and strains, whereas W6-GFRP, had an increase but at a lower rate.

Fig. 7 Summary of stress/strain graphs for the tested specimens

Stress-strain curve starts with a steep slope indicating the linear stage of masonry, whereas the second stage indicates the plastic phase and it is almost horizontal that usually started after the cracks became visible to naked eye. In this stage, the

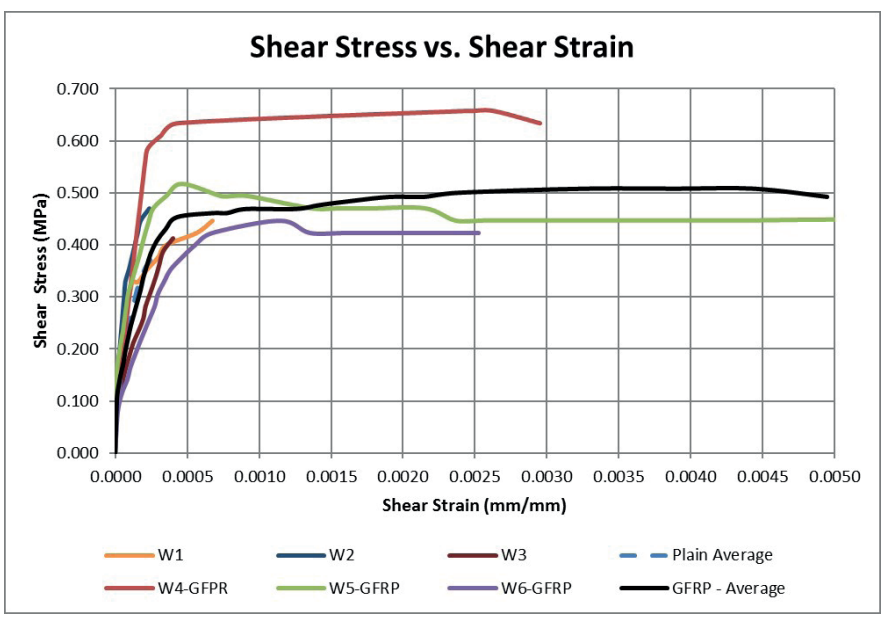

degraded stiffness can be observed.

For the plain panels, the average shear strength was 0.423 $\mathrm{MPa}$, with a maximum value of $0.470 \mathrm{MPa}$ occurring at $\mathrm{W} 2$ and a minimum value of $0.352 \mathrm{MPa}$ occurring at $\mathrm{W} 3$. The average drift was calculated to be $0.058 \%$, with a maximum value of $0.083 \%$ occurring at W3 and a minimum of $0.024 \%$ occurring at W2.

GFRP reinforced panels achieved higher values of shear strengths and ultimate drifts. These panels exhibited a more ductile behaviour when compared to plain panels. The average shear strength was $0.538 \mathrm{MPa}$, with a maximum value of 0.675 MPa occurring at W4-GFRP and a minimum value of 0.446 MPa occurring at W6-GFRP. The average drift was calculated to be $0.637 \%$, with a maximum value of $0.975 \%$ occurring at W5-GFRP and a minimum of $0.253 \%$ occurring at W6-GFRP. A summary of mechanical parameters of the tested specimens is presented in Table 2 . 
Table 2 Summary of mechanical parameters for the tested specimens

\begin{tabular}{|c|c|c|c|c|c|c|c|c|c|}
\hline 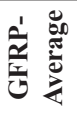 & 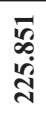 & ஸี & חீ & 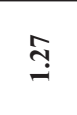 & ڤુ & $\begin{array}{l}\ddot{\infty} \\
\hat{\theta}\end{array}$ & $\begin{array}{l}\hat{b} \\
\dot{n} \\
\frac{n}{2}\end{array}$ & 号 & 乎 \\
\hline 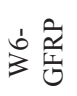 & $\begin{array}{l}\frac{0}{m} \\
\infty \\
\infty\end{array}$ & $\stackrel{\wp}{\circ}$ & \begin{tabular}{l}
$\stackrel{0}{8}$ \\
\multirow{8}{*}{}
\end{tabular} & $\stackrel{n}{0}$ & 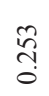 & 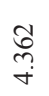 & $\stackrel{\infty}{m}$ & ڤ్ & ڤે \\
\hline$\stackrel{n}{n} \frac{a}{0}$ & 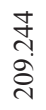 & $\begin{array}{l}\hat{6} \\
ت\end{array}$ & 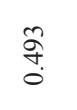 & $\stackrel{F}{ت}$ & $\frac{n}{a}$ & $\begin{array}{l}0 \\
\infty \\
0 \\
0\end{array}$ & d & 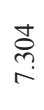 & $\frac{\sigma}{6}$ \\
\hline 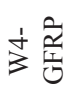 & 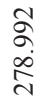 & $\begin{array}{l}\stackrel{0}{n} \\
n\end{array}$ & $\begin{array}{l}n \\
6 \\
0\end{array}$ & $\stackrel{?}{\circ}$ & $\begin{array}{l}+ \\
\infty \\
0 \\
0\end{array}$ & $\begin{array}{l}\varrho \\
\equiv\end{array}$ & 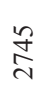 & $\stackrel{\hat{n}}{\infty}$ & $\begin{array}{l}\hat{\delta} \\
0\end{array}$ \\
\hline 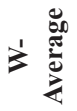 & 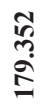 & ' & $\stackrel{\overbrace{}}{+}$ & ' & $\stackrel{\infty}{\mathscr{0}}$ & ' & $\frac{m}{m}$ & 1 & $\begin{array}{l}m \\
\ddot{m} \\
\ddot{\infty}\end{array}$ \\
\hline$\hat{\beta}$ & $\begin{array}{l}\stackrel{0}{+} . \\
\stackrel{g}{+}\end{array}$ & ' & त̃ & ' & $\begin{array}{l}\mathscr{0} \\
0 \\
0\end{array}$ & ' & $\stackrel{+}{2}$ & ' & $\tilde{6}$ \\
\hline$\stackrel{1}{3}$ & $\begin{array}{l}\stackrel{\infty}{\sim} \\
\stackrel{2}{g}\end{array}$ & 1 & fं & ' & $\underset{ర}{\stackrel{\Xi}{0}}$ & ' & $\stackrel{゚}{\stackrel{一}{+}}$ & 1 & \& \\
\hline$\overline{3}$ & $\begin{array}{l}0 \\
\stackrel{m}{0} \\
\infty\end{array}$ & ' & $\stackrel{0}{\stackrel{+}{+}}$ & I & $\begin{array}{l}\infty \\
0 \\
0 \\
0\end{array}$ & ' & సి & ' & $\stackrel{n}{\infty}$ \\
\hline$\frac{\sqrt{\Xi}}{\vdots}$ & 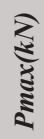 & 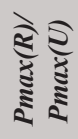 & 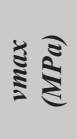 & 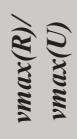 & $e^{e}$ & $\frac{\mathfrak{Ð}}{\mathfrak{\S}}$ & $\underbrace{\Xi}_{0}$ & $\begin{array}{l}\frac{\mathfrak{s}}{0} \\
\frac{1}{\mathfrak{s}}\end{array}$ & 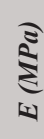 \\
\hline
\end{tabular}

$\boldsymbol{P}_{\text {max }}$-is the ultimate diagonal load; $\boldsymbol{P}_{\text {max }}(\boldsymbol{R}) \boldsymbol{P}_{\text {max }}(\boldsymbol{U})$ - the ratio of ultimate diagonal load of the reinforced panel over the average ultimate load of the plain panel; $\boldsymbol{v}_{\max }$ - the maximum shear strength; $\boldsymbol{v}_{\max }(\boldsymbol{R}) / \boldsymbol{v}_{\max }(\boldsymbol{U})$ the ratio of the shear strength of the reinforced panel over the average shear strength of the plain panel; $\gamma_{u}$-ultimate drift; $\gamma_{u}(\boldsymbol{R}) / \gamma_{u}(\boldsymbol{U})$-the ratio of ultimate drift of the reinforced panel over the average ultimate drift of the plain panel; $G$ modulus of rigidity (shear modulus); $\boldsymbol{G}(\boldsymbol{R}) / \boldsymbol{G}(\boldsymbol{U})$ - the ratio of the modulus of rigidity of the reinforced panel over the modulus of rigidity of the plain panel; $\boldsymbol{E}$ - modulus of elasticity.

The reinforced panels exhibited an average of 1.27 times higher shear strength, were almost 11 times more ductile and had a 6.45 times higher shear modulus when compared to the plain ones. The effect of shear resistance is not very considerable due to the overall high shear strength of the panels due to the compressive strength of the "N" type mortar. From another study of the author, it was observed that the effectiveness of the external shear strengthening techniques in masonry was higher when the mortar compressive strength was low [49].

The GFRP mesh plays an important role in restraining and confining the masonry units. The overall reinforcing system prevents the abrupt decrease of resistance and significantly reduces the brittle behavior of the panel by avoiding the sudden collapse.

\section{Conclusions}

In this paper are reported the experimental results of diagonal compression tests on three unreinforced and three G-FRP reinforced panels of nominal dimensions $1200 \times 1200 \times 250$ $\mathrm{mm}$ to determine the effectiveness of the in-plane strengthening technique of GFRP mesh jacketing embedded in an inorganic matrix made of cement-base mortar applied on both sides of solid brick masonry panels.

The reinforced panels exhibited an average increase of $127 \%$ of shear resistance, $1100 \%$ increase in ductility and $645 \%$ increase in shear modulus.

It was concluded that this technique provided satisfactory results and can be considered a suitable method for repair of masonry structures.

\section{References}

[1] Lourenço, P. B. "Computational strategies for masonry structures". PhD Thesis. Delft University of Technology, Delft, Netherlands, 1996.

[2] Faella, C., Martinelli, E., Nigro, E., Paciello, S. "Shear capacity of masonry walls externally strengthened by a cement-based composite material: An experimental campaign". Construction and Building Materials, 24(1), pp. 84-93. 2010. https://doi.org/10.1016/j.conbuildmat.2009.08.019

[3] Kalali, A., Kabir, M. Z. "Experimental response of double-wythe masonry panels strengthened with glass fiber reinforced polymers subjected to diagonal compression tests". Engineering Structures, 39, pp. 24-37. 2012. https://doi.org/10.1016/j.engstruct.2012.01.018

[4] Triantafillou, T. C. "Strengthening of masonry structures using epoxy-bonded FRP laminates". ASCE Journal of Composites for Construction, 2(2), pp. 96-104. 1998. https://doi.org/10.1061/(ASCE)10900268(1998)2:2(96)

[5] Rosenthal, I. "Precast ferrocement columns". Journal of Ferrocement, 16, pp. 273-284. 1986.

[6] Winokur, A., Rosenthal, I. "Ferrocement in centrally loaded compression elements". Journal of Ferrocement, 12, pp. 357-364. 1982.

[7] Razvi, S., Saatcioglu, M. "Confinement of reinforced concrete columns with welded wire fabric". ACI Structural Journal, 86(5), pp. 615-623. 1989.

[8] Mourad, S. M., Shannag, M. J. "Repair and strengthening of reinforced concrete square columns using ferrocement jackets". Cement \& Concrete Composites, 34(2), pp. 288-294. 2012. https://doi.org/10.1016/j.cemconcomp. 2011.09.010

[9] Kaushik, S., Prakash, A., Singh, A. "Inelastic buckling of ferrocement encased columns". In: Ferrocement: Proceedings of the Fifth International Symposium on Ferrocement UMIST, Manchester, 6-9 Sept. 1994. (Nedwell, P. J., Swamy, R. N. (Eds.)). Taylor \& Francis, 1994. e-book.

[10] Ahmed, T., Ali, S., Choudhury, J. "Experimental study of ferrocement as a retrofit material for masonry columns". In: Ferrocement: Proceedings of the Fifth International Symposium on Ferrocement UMIST, Manchester, 6-9 Sept. 1994. (Nedwell, P. J., Swamy, R. N. (Eds.)). Taylor \& Francis, 1994. e-book.

[11] Forta Ferro Corporation, "Forta for Concrete". September 2015. [Online]. Available: www.forta-ferro.com.

[12] American Concrete Institute. "State-of-the-art Report on Fiber Reinforced Concrete". ACI, 2002.

[13] Yardim, Y., Lalaj, O. "Shear strengthening of unreinforced masonry wall with different fiber reinforced mortar jacketing". Construction and Building Materials, 102(Part 1), pp. 149-154. 2016. https://doi.org/10.1016/j. conbuildmat.2015.10.095

[14] Mustafaraj, E., Yardim, Y. "External shear strengthening of unreinforced masonry panels using ferrocement jacketing". In: XVI International Scientific Conference VSU, 9-10. June, Sofia, Bulgaria. 2016.

[15] Mustafaraj, E., Yardim, Y. "Usage of ferrocement jacketing for strengthening of damaged unreinforced masonry (URM) walls". In: 3rd International Balkans Conference on Challenges of Civil Engineering. pp. 153-163. 19-21 May, Tirana, Albania. 2016. http://dspace.epoka.edu.al/bitstream/ handle/1/1558/STR-153-163.pdf?sequence=1\&isAllowed=y 
[16] Papanicolaou, C., Triantafillou, T., Lekka, M. "Externally bonded grids as strengthening and seismic retrofitting materials for masonry panels". Construction and Building Materials, 25(2), pp. 504-514. 2001. https:// doi.org/10.1016/j.conbuildmat.2010.07.018

[17] Nanni, A., Tumialan, J. "Fiber reinforced composites for strengthening of masonry structures". Structural Engineering International, 13(4), pp. 271-278. 2003. https://doi.org/10.2749/101686603777964360

[18] Zhao, T., Xie, J., Li, H. "Strengthening of cracked concrete block masonry walls using continuous carbon fiber sheet". In: 9th NAMC, Clemson, South Carolina, USA, 2003.

[19] Hamoush, S., McGinley, W., Mlakar, P., Scott, D., Murray, K. "Out-ofplane strengthening of masonry walls with reinforced composites". ASCE Journal of Composites for Construction, 5(3), pp. 139-145. 2001. https:// doi.org/10.1061/(ASCE)1090-0268(2001)5:3(139)

[20] Gilstrap, J., Dolan, C. "Out of plane bending of FRP-reinforced masonry walls". Composites Science and Technology, 58(8), pp. 1277-1284. 1998. https://doi.org/10.1016/S0266-3538(98)00007-4

[21] Gabor, A., Bennani, A., Jacquelin, E., Lebon, F. "Modelling approaches of the in-plane shear behaviour of unreinforced and FRP strengthened masonry panels". Composite Structures, 74(3), p. 277-288. 2006. https://doi. org/10.1016/j.compstruct.2005.04.012

[22] Valluzzi, M. R., Tinazzi, D., Modena, C. "Shear behavior of masonry panels strengthened by FRP laminates". Construction and Building Materials, 16(7), pp. 409-416. 2002. https://doi.org/10.1016/S0950-0618(02)00043-0

[23] Gattesco, N., Boem, I. "Experimental and analytical study to evaluate the effectiveness of an in-plane reinforcement for masonry walls using GFRP meshes". Construction and Building Materials, 88, 94-104. 2015. 10.1016/j.conbuildmat.2015.04.014

[24] CEN. "EN 1996-1-1: Design of masonry structures - Part 1-1: General rules for reinforced and unreinforced masonry structures". European Committee for Standardization, Brussels, Belgium, 2005.

[25] Tomazevic, M., Klemenc, I. "Seismic behaviour of confined masonry walls". Earthquake Engineering Structural Dynamics, 26(10), pp. 1059-1071. 1997. https://doi.org/10.1002/(SICI)10969845(199710)26:10<1059::AID-EQE694>3.0.CO;2-M

[26] Atkinson, R. H., Amadei, B. P., Saeb, S., Sture, S. "Response of masonry bed joints in direct shear". ASCE Journal of Structural Engineering, 115(9), pp. 2276-2296. 1989. https://doi.org/10.1061/(ASCE)07339445(1989)115:9(2276)

[27] El-Sakhawy, N. R., Raof, H. A., Gouhar, A. "Shearing behaviour of joints in load bearing masonry wall". Journal of Materials in Civil Engineering, 14(2), pp. 145-150. 2002. https://doi.org/10.1061/(ASCE)08991561(2002)14:2(145)

[28] Abdou, L., Saada, R. A., Meftah, F., Mebarki, A. "Experimental investigations of the joint-mortar behaviour". Mechanics Research Communications, 33(3), pp. 370-384, 2006.

[29] Maheri, M. R., Sherafati, M. A. "The effects of humidity and other environmental parameters on the shear strength of brick walls; evaluation of field test data". Materials and Structures, 45(6), pp. 941-956. 2012. https://doi.org/10.1617/s11527-011-9809-7

[30] Chiozzi, A., Miranda, E. "Fragility functions for masonry infill walls with in-plane loading". Earthquake Engineering \& Structural Dynamics, 46(15), pp. 2831-2850. 2017. https://doi.org/10.1002/eqe.2934

[31] Najafgholipour, M. A., Maheri, M. R., Lourenço, P. B. "Capacity interaction in brick masonry under simultaneous in-plane and out-of-plane loads". Construction and Building Materials, 38, pp. 619-626. 2013. https://doi.org/10.1016/j.conbuildmat.2012.08.032

[32] Dizhur, D., Ingham, J. M. "Diagonal tension strength of vintage unreinforced clay brick masonry wall panels". Construction and Building Materials, 43, pp. 418-427. 2013. https://doi.org/10.1016/j.conbuildmat. 2013.02.015
[33] Badoux, M., Elgwady,M. A., Lestuzzi, P. "Earthquake Simulator Tests on Unreinforced Masonry Walls before and after Upgrading with Composites". In: 12th European Conference on Earthquake Engineering. 9-13. Sept. 2002. Barbicon Centre. London, UK. 2002.

[34] Turco, V., Secondin, S., Morbin, A., Valluzzi, M. R., Modena, C. "Flexural and shear strengthening of un-reinforced masonry with FRP bars". Composites Science and Technology, 66(2), pp. 289-296. 2006. https:// doi.org/10.1016/j.compscitech.2005.04.042

[35] Fam, A., Musiker, D., Kowalsky, M., Rizkalla, S. "In-plane testing of damaged masonry wall repaired with FRP". Advanced Composites Letters, 11(6), pp. 275-281. 2002.

[36] Wang, Q., Chai, Z., Huang, Y., Zhang, Y. "Seismic shear capacity of brick masonry wall reinforced by GFRP". Asian Journal of Civil Engineering (Building and Housing), 7(6), pp. 563-580. 2006.

[37] Corradi, M., Borri, A., Vignoli, A. "Strengthening techniques tested on masonry structures struck by the Umbria-Marche earthquake of 19971998". Construction and Building Materials, 16(4), pp. 229-239. 2002. https://doi.org/10.1016/S0950-0618(02)00014-4

[38] Corradi, M., Borri, A., Castori, G., Sisti, R. "Shear strengthening of wall panels through jacketing with cement mortar reinforced by GFRP grids". Composites Part B: Engineering, 64, pp. 33-42. 2014. https://doi. org/10.1016/j.compositesb.2014.03.022

[39] Al-Salloum, Y. A., Almusallam, T. H. "Load Capacity of Concrete Masonry Block Walls strengthened with epoxy-bonded GFRP sheets". Journal of Composite Materials, 39(19), pp. 1719-1745. 2005. https://doi. org/10.1177/0021998305051119

[40] Mahmood, H., Russel, A. P., Ingham, J. M. "Monotonic testing of unreinforced and FRP-retrofitted masonry walls prone to shear failure in an earthquake". In: Proceedings of the 14th world conference on earthquake engineering, Beijing, China. 2008.

[41] Drysdale, R., Hamid, A., Baker, L. "Masonry Structures: Behaviour and Design". The Masonry Society. 1999.

[42] Croci, G. "The conservation and structural restoration of the architectural heritage". Computational Mechanics Publications, Southampton, UK. 1998.

[43] Mustafaraj, E. "Assessment of historical structures: A case study of five Ottoman mosques in Albania". LAP Lambert Academic Publishing, Germany. 2014.

[44] Wood, W. A. "Load distribution of masonry walls subject to concentrated loads over openings". University of Pittsburgh, Pittsburgh, USA. 1998.

[45] Pande, G., Middleton, J., Krajl, B. "Computer Methods in structural masonry". E \& FN Spon, London, UK. 1998. https://dl.acm.org/citation. cfm?id=552320

[46] Borri, A., Castori, G., Corradi, M., Speranzini, E. "Shear behavior of unreinforced and reinforced masonry panels subjected to in situ diagonal compression tests". Construction and Building Materials, 25(12), pp. 4403-4414. 2011. https://doi.org/10.1016/j.conbuildmat.2011.01.009

[47] Borri, A., Castori, G., Corradi, M., "Determination of shear strength of masonry panels through different tests". International Journal of Architectural Heritage, 9(8), pp. 913-927. 2015. https://doi.org/10.1080/1558305 8.2013 .804607

[48] Brignola, A., Frumento, S., Lagomarsino, S., Podesta, S. "Identification of shear parameters of masonry panels through the in-situ diagonal compression test". International Journal of Architectural Heritage, 3(1), pp. 52-73. 2008. 10.1080/15583050802138634

[49] Mustafaraj, E. "External shear strengthening of unreinforced damaged masonry walls". PhD Thesis, Epoka University, Tirana, Albania. 2016. 